\title{
MODERN INDONESIAN LITERATURE IN TRANSLATION I
}

\author{
(Compiled by Dede Oetomo)
}

It is a long time since a bibliography has appeared of English translations of modern Indonesian poems, plays, short stories, and novels, and there is currently enough teaching on Indonesia in English-language schools and colleges for us to think that such a bibliography might be helpful. This bibliography, which has been divided into two sections, relies heavily on earlier collections of Indonesian literature in translation, and a list of the principal sources from which these translations have been drawn appears at the beginning of each section.

The first part of the bibliography is entirely devoted to the poetry of Chairil Anwar, who is perhaps the Indonesian poet best known among Westerners. Chairil Anwar died in 1949 at the age of twenty-seven and published only about seventyfour poems. Nevertheless, translations of his poetry form about a third ( 371 titles) of the total number of English translations of Indonesian literary works that have thus far appeared. For ease in comparing the different English versions, we have listed the poems alphabetically under their Indonesian titles, with the various translations arranged alphabetically by translator (if his name is known), and the date when the translation appeared. If the English version is accompanied by the original Indonesian poem, the letters BT (Bilingual Text) follow the entry.

The forthcoming issue of Indonesia will continue this bibliography, and will include English translations of other Indonesian poets, and of short stories, novels, and the few Indonesian plays that have been translated into English.

\section{SOURCES}

Ali, Flaming Earth

Aveling, "World"

Beier, Only Dust
Ali, Ahmed, ed., tr. The Flaming Earth: Poems from Indonesia. Karachi: Friends of the Indonesian People Society, 1949.

Aveling, Harry. "The World of Chairil Anwar," Lachesis (Winter 1967), pp. 7-13.

Only Dust: Three Modern Indonesian Poets. English version by Ulli Beier. Port Moresby, New Guinea: Papua Pocket Poets, 1969. 
Boen, Chairil Anwar

Dickinson, Sharp Gravel

Dickinson, "Selected Social \& Ethical Values"

Echols, IWT

José, Asian PEN

Liaw Yock Fang, $C P$

Muhammad Haji Salleh, Tradition and Change

Moerdowo, Sociological Aspects

Nababan, "Linguistic Analysis"

Raffel, AMIP

Raffel, "Beginnings"

Raffel, "Chairil Anwar"

Raffel, Development
Oemarjati, Boen S. Chairil Anwar: The Poet and His Language. Verhandelingen van het Koninklijk Instituut voor Taal-, Land- en Volkenkunde, 63. The Hague: Nijhoff, 1972.

Dickinson, Donna M. Sharp Gravel. Berkeley: CSEAS, [c. 1960].

Dickinson, Donna M. "Selected Social and Ethical Values in Indonesian Literature, 1900-1960." Ph.D. dissertation, University of California at Berkeley, 1963.

Echols, John M. Indonesian Writing in Translation. Ithaca: Cornell Modern Indonesia Project, 1956.

Sionil, José F. Asian PEN Anthology. Manila: Solidaridad, 1966 (New York: Taplinger Publishing, 1967).

Liaw Yock Fang, ed., tr. The Complete Poems of Chairil Anwar. Singapore: University Education Press, 1974.

Salleh, Muhammad Haji. Tradition and Change in Contemporary Malay-Indonesian Poetry. Kuala Lumpur: Universiti Kebangsaan Malaysia, 1977.

Moerdowo, Raden. Sociological Aspects of Modern Indonesian Literature. London: Cultural Department, Embassy of the Republic of Indonesia, 195?.

Nababan, Sri Utari Subjakto. "A Linguistic Analysis of the Poetry of Amir Hamzah and Chairil Anwar." Ph.D. dissertation, Cornell University, 1966.

Raffel, Burton, ed. An Anthology of Modern Indonesian Poetry. Berkeley and Los Angeles: University of California Press, 1964.

Raffel, Burton. "The Beginnings of Modern Indonesian Poetry," Asia, no. 2 (Autumn 1964), pp. 67-79.

Raffel, Burton. "Chairil Anwar--Indonesian Poet," The Literary Review, 10 (Winter 1966-67), pp. 133-57.

Raffel, Burton. The Development of Modern Indonesian Poetry. Albany: SUNY Press, 1967. 
Raffel, CPP

Raffel \& Salam, SP

Shimer, Mentor Book

$S I L$

Teeuw, MIL

Wigmore, Span
Raffel, Burton, ed., tr. The Complete Poetry and Prose of Chairil Anwar. Albany: SUNY Press, 1970.

Raffel, Burton, and Salam, Nurdin. Chairil Anwar: Selected Poems. New York: New Directions, 1963.

Shimer, Dorothy Blair, ed. The Mentor Book of Modern Asian Literature, from the Khyber Pass to Fuii. New York: The New American Library, 1969.

Survey of Indonesian Literature. New York: Indonesian Information Office, 1953.

Teeuw, A. Modern Indonesian Literature. The Hague: Nijhoff, 1967.

Wigmore, Lionel, ed. Span: An Adventure in Asian and Australian Writing. Melbourne: Cheshire, 1958. 


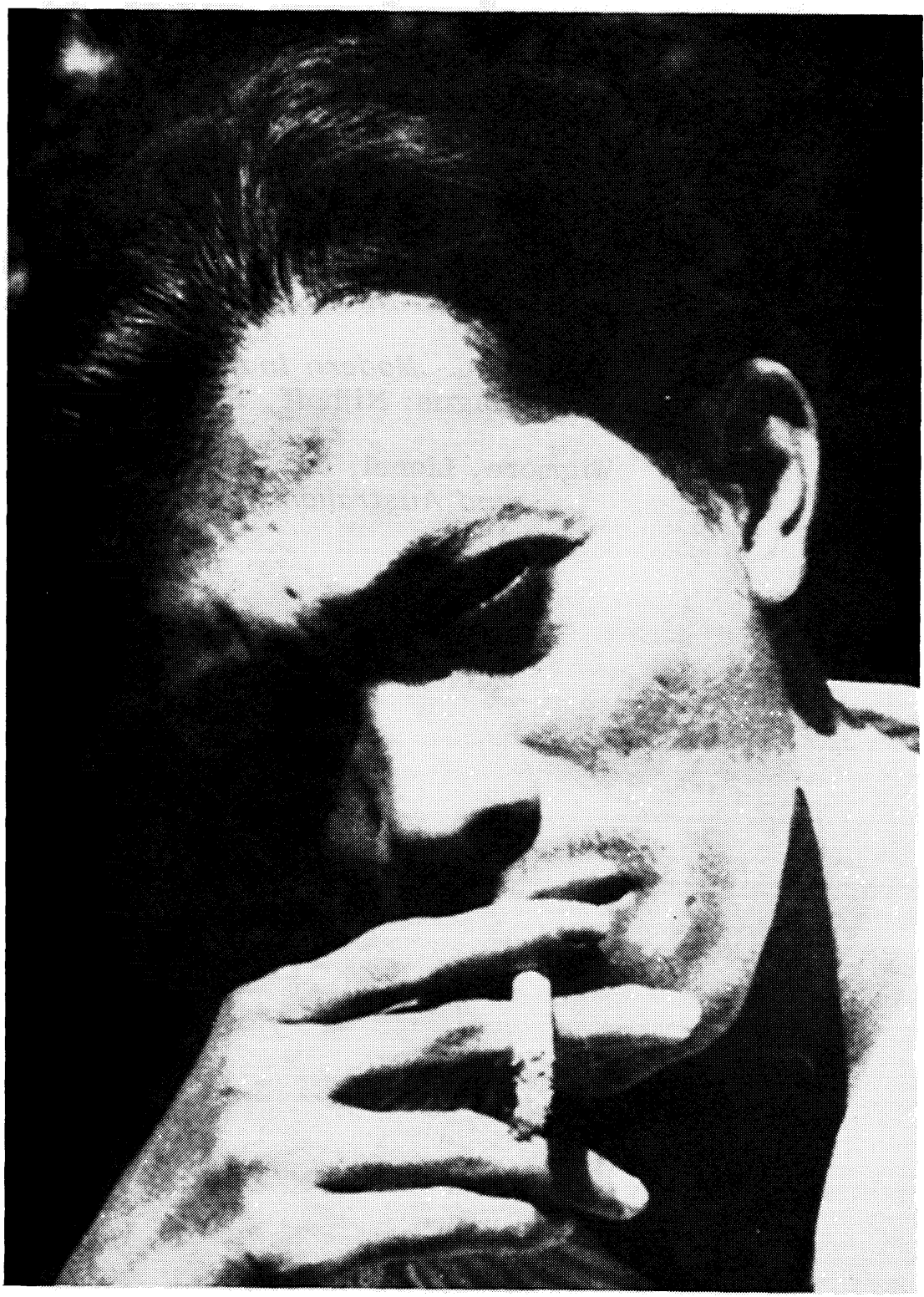

CHAIRIL ANWAR. 
POETRY

\section{Chairil Anwar}

Adjakan

Aku

Aku berada kembali banjak jang asing (originally untitled)

Aku berkisar antara mereka

Aku (semangat)
"An appeal," tr. Dickinson, in Sharp Gravel, pp. 54$55(\mathrm{BT})$.

"A solicitation," tr. Liaw Yock Fang, in CP, pp. 16-17 (BT).

"Invitation," tr. Raffel, in Keith Foulcher, "Some considerations on the approach to modern Indonesian literature," Review of Indonesian and Malayan Affairs, 2 (1968), pp. 30-31 (BT).

"Invitation," tr. Raffel, in CPP, pp. 12-13 (BT).

"Invitation," tr. Raffel \& Salam, in $S P, \mathrm{p} .45$.

"Invitation," tr. Raffel \& Salam, in Raffel, Development, p. 110 .

"I," tr. Dickinson, in Sharp Gravel, pp. 68-69 (B T).

"I," tr. Liaw Yock Fang, in CP, pp. 48-49 (BT).

"Me," tr. Raffel, in CPP, pp. 46-47 (B T).

"I come back . . .," tr. Liaw Yock Fang, in CP, pp. 126-27.

"I'm back again," tr. Raffel, in CPP, pp. 156-57.

"I go about among them," tr. Boen S. Oemarjati, in Chairil Anwar, p. 94 (B T).

"I go among them," tr. Liaw Yock Fang, in CP, pp. 120-21 (BT).

"I run around with them," tr. Raffel, in CPP, pp. 144-45 (B T).

"When death will come," tr. Ahmed Ali, in Mochtar Lubis, "Contemporary Indonesian literature," United Asia, 4, 3 (1952), p. 157.

"I," tr. Harry Aveling, in "World," pp. 8-9.

"I," tr. M. Balfas, in Education and Culture (Jakarta), 1,4 (1951), p. 4 .

"I," tr. M. Balfas, in Asia [Saigon], 1, 4 (1952), p. 515.

"My spirit," tr. Dickinson, in Sharp Gravel, pp. 40-41 (BT).

"Me (spirit)," tr. Liaw Yock Fang, in CP, pp. 24-25 (BT). 
Aku (semangat) (continued)

Bertjerai

"Betina"-nja 'Affandi

Biar malam kini lalu (originally untitled)
"Me," tr. Muhammad Haji Salleh, in Tradition and Change, pp. 11-12 (B T).

"Me," tr. Moerdowo, in Sociological Aspects, p. 11.

"Me," tr. Nababan, in "Linguistic Analysis," pp. 149-50 (B T).

"Me," tr. Raffel, in CPP, pp. 20-21 (BT).

"Me," tr. Raffel \& Salam, in Echols, IWT, p. 66.

"Me," tr. Raffel \& Salam, in $S P$, p. 30.

"Me," tr. Raffel \& Salam, in Poetry Northwest, 4, 3/4 (1963/64), pp. 66-67 (BT).

"Me," tr. Raffel \& Salam, in Raffel, "The Beginnings," pp. 78-79.

"Me," tr. Raffel \& Salam, in Ahar, "Menjambut Selected Poems of Chairil Anwar" (review article), Basis, 13, 6 (1964), p. 175 .

"Me," tr. Raffel \& Salam, in Raffel, "Chairil Anwar," p. 139.

"Me," tr. T. P. C. Sutopo, in "An introduction to Indonesian literature," Indonesian Review, 2 (Jan./Mar., 1954), p. 66 (BT).

"When death will come," originally tr. Rowena Vining, in Ali, Flaming Earth, p. 11.

"When death comes," tr. Rowena Vining, in United Asia (Bombay), 4, 3 (1952), p. 157

"Me," tr. Rowena Vining, in $S / L, p .10$.

"I" (tr. not mentioned), in Modern Literature in Indonesia (New York: Indonesian Information Office, n.d.), p. 4 .

"Separation," tr. Beier, in Only Dust, p. 15.

"Parting," tr. Dickinson, in Sharp Gravel, pp. 72-73 (BT).

"Parting," tr. Liaw Yock Fang, in CP, pp. 46-47 (BT).

"Parting," tr. Raffel, in CPP, pp. 32-33 (BT).

"Parting," tr. Raffel \& Salam, in SP, p. 32.

"The woman of Affandi," tr. Liaw Yock Fang, in $C P$, pp. 94-95 (B T).

"Affandi's slut," tr. Raffel, in CPP, pp. 108-9 (BT).

"Let this night pass away," tr. Liaw Yock Fang, in $C P$, pp. 124-25 (BT).

"Let this evening go by," tr. Raffel, in CPP, pp. 154-55 (B T). 
Buat album D.S.

Buat Gadis Rasid

Buat Njonja $\mathrm{N}$.

Dalam kereta

Dari dia

Dendam

Derai-derai tjemara
"The sailor hears a song," tr. Beier, in Only Dust, p. 17.

"For D.S.'s album," tr. Liaw Yock Fang, in $C P$, pp. 82-83 (B T).

"D.S.: For her album," tr. Raffel, in CPP, pp. 94-95 (BT).

"To Gadis," tr. Ali, in Flaming Earth, p. 13.

"To Gadis," tr. Ahmed Ali, in Wigmore, ed., Span, p. 246 .

"For a girl called Rasid," tr. Aveling, in "World," pp. 12-13.

"To Miss Gadis Rasid," tr. Liaw Yock Fang, in CP, pp. 112-13 (B T).

"For Miss Gadis Rasid," tr. Raffel, in CPP, pp. 140-41 (B T).

"To Mrs. N.," tr. Liaw Yock Fang, in CP, pp. 118-19 (BT).

"For Mrs. N.," tr. Raffel, in CPP, pp. 146-47 (B T).

"In a train," tr. Liaw Yock Fang, in CP, pp. 68-69 (BT).

"In the train," tr. Raffel, in CPP, pp. 74-75 (BT).

"In the train," tr. Raffel \& Salam, in Raffel, Development, p. 101.

"From him," tr. Liaw Yock Fang, in CP, pp. 96-97 (BT).

"From her," tr. Raffel, in CPP, pp. 112-13 (BT).

"Desire for revenge," tr. Dickinson, in Sharp Gravel, pp. 76-77 (BT).

"Hatred," tr. Liaw Yock Fang, in CP, pp. 56-57 (B T).

"Revenge," tr. Raffel, in CPP, pp. 58-59 (BT).

"Whispering pines," tr. Boen, in Chairil Anwar, p. 107 (B T).

"The pines extend to the distance," tr. A. H. Johns, $B K I, 120,4$ (1964), pp. 402-3, 408 (BT).

"The fir tree rustles far away," tr. Liaw Yock Fang, in $C P$, pp. 122-23 (BT).

"Fir trees in rows," tr. Raffel, in CPP, pp. 152-53 (BT).

"The casuarinas straggle into the distance," tr. A. Teeuw (based on A. H. John's translation), MIL, pp. $150-51,266-67$ (BT). 
Di Mesdjid

Diponegoro

Doa
"At the mosque," tr. Boen, in Chairil Anwar, p. 59 (B T).

"At the mosque," tr. Dickinson, in Sharp Gravel, pp. 66-67.

"In the mosque," tr. Dickinson, in "Selected Social \& Ethical Values," pp. 138-39.

"At the mosque," tr. A. H. Johns, BKI, 120, 4 (1964), pp. 400,407 .

"At the mosque," tr. Liaw Yock Fang, in CP, pp. 5253 (B T).

"In the mosque," tr. Muhammad Haji Salleh, Tradition and Change, pp. 22 (B T).

"At the mosque," tr. Nababan, "Linguistic Analysis," pp. 175-76 (BT).

"At the mosque," tr. Raffel, in "Indonesian Poetry: an introduction," Texas Quarterly, 6, 3 (1963), p. 101.

"At the mosque," tr. Raffel, in CPP, pp. 50-51 (BT).

"At the mosque," tr. Raffel \& Salam, in $S P, p .36$.

"At the mosque," tr. Raffel \& Salam, in Raffel, "Chairil Anwar," p. 146.

"At the mosque," tr. Raffel \& Salam, in Shimer, Mentor Book, p. 67.

"Diponegoro," tr. Boen, in Chairil Anwar, p. 27 (BT).

"Dipo Negoro--Indonesian hero," tr. Dickinson, in Sharp Gravel, pp. 28-29 (B T).

"Diponegoro--Indonesian hero," tr. Dickinson, in "Selected Social \& Ethical Values," pp. 144-45 (B T).

"Dipo Negoro," tr. Liaw Yock Fang, in CP, pp. 10-11.

"Diponegoro," tr. Nababan, in "Linguistic Analysis," pp. $165-66$ (B T).

"Diponegoro," tr. Raffel, in CPP, pp. 6-7 (BT).

"Prayer," tr. Dickinson, in "Selected Social \& Ethical Values," pp. 140-41.

"Prayer," tr. Liaw Yock Fang, in CP, pp. 66-67.

"Prayer," tr. Raffel, in CPP, pp. 70-71 (BT).

"A prayer," tr. A. H. Johns, BKI, 120, 4 (1964), pp. $401,407-8$.

"Prayer," tr. A. Teeuw (based on A. H. Johns' translation), in Teeuw, MIL, pp. 155-56, 267-68 (BT). 
Hampa

Hukum

Ina mia

Isa

Jang terampas dan jang luput

Kabar dari laut
"Empty," tr. Aveling, in "World," p. 10.

"Futility," tr. Aveling, in Thematic History, p. 29 (BT).

"Empty," tr. Boen, in Chairil Anwar, p. 53 (BT).

"Empty," tr. Dickinson, in Sharp Gravel, pp. 58-59 (BT).

"Empty," tr. Liaw Yock Fang, in CP, pp. 42-43 (BT).

"Empty," tr. Raffel, in CPP, pp. 40-41 (BT).

"Empty," tr. Raffel \& Salam, in $S P, p .26$.

"Empty," tr. Raffel \& Salam, in Poetry Northwest, 4, $3 / 4(1963 / 64)$, pp. 62-63 (BT).

"Doomed," tr. Dickinson, in Sharp Gravel, pp. 42-43 (B T).

"Law," tr. Liaw Yock Fang, in CP, pp. 26-27 (BT).

"The law," tr. Raffel, in CPP, pp. 22-23 (BT).

"Ina mia," tr. John Kleinig, in Indonesia, special issue of Westerly, Oct. 1966, p. 22.

"Ina mia," tr. Liaw Yock Fang, in CP, pp. 108-9 (BT).

"Ina mia," tr. Raffel, in CPP, pp. 134-35 (B T).

"Ina mia," tr. Raffel \& Salam, in $S P$, p. 34.

"Jesus," tr. Boen, in Chairil Anwar, p. 68 (BT).

"Jesus," tr. Liaw Yock Fang, in CP, pp. 64-65 (B T).

"Jesus Christ," tr. Raffel, in CPP, pp. 68-69 (BT).

"The ravaged and the broken," tr. Boen, in Chairil Anwar, p. 103.

"The deprived and the escaped," tr. Liaw Yock Fang, in $C P$, pp. 118-19 (B T).

"He who is smashed and broken," tr. Nababan, in "Linguistic Analysis," pp. 184-85.

"Some are plundered, some escape," tr. Raffel, in CPP, pp. $150-51$ (BT).

"The captured and the freed," tr. Raffel \& Salam, in $S P, \mathrm{p} .18$.

"The captured and the freed," tr. Raffel \& Salam, in Raffel, "Chairil Anwar," p. 157.

"The captured and the freed," tr. Raffel \& Salam, in Raffel, Development, p. 109.

"Letter from the sea," tr. Beier, in Only Dust, p. 14. 
Kabar dari laut (continued)

Kawanku dan aku

Kenangan

Kepada kawan

Kepada pelukis Affandi
"News from the sea," tr. Liaw Yock Fang, in $C P$, pp. 88-89 (BT).

"News from the sea," tr. Raffel, in CPP, pp. 102-3 (B T).

"News from the sea," tr. Raffel \& Salam, in Raffel, "Chairil Anwar," pp. 148-49.

"News from the sea," tr. Raffel \& Salam, in Raffel, Development, p. 102.

"My friend and I," tr. Dickinson, in Sharp Gravel, pp. 64-65 (B T).

"My self and a companion," tr. A. H. Johns, $B K I, 120$, 4 (1964), pp. 399, 406-7 (B T).

"My friend and me," tr. Liaw Yock Fang, in $C P$, pp. 44-45 (BT).

"My friend and I," tr. Raffel, in CPP, pp. 42-43 (BT).

"My friend and I," tr. Raffel \& Salam, in SP, p. 29.

"My friend and I," tr. A. Teeuw, in his "My Friend and I," in Spectrum: Essays presented to Sutan Takdir Alisjahbana on his seventieth birthday, ed. S. Udin (Jakarta: Dian Rakyat, 1978), p. 157.

"Memories," tr. Boen, in Chairil Anwar, p. 44 (BT).

"To the memory of Karinah Moordjono," tr. Dickinson, in Sharp Gravel, pp. 56-57 (BT).

"Memories," tr. Liaw Yock Fang, in CP, pp. 40-41 (B T).

"Memories," tr. Nababan, in "Linguistic Analysis," p. 171 (B T).

"Memories," tr. Raffel, in CPP, pp. 36-37 (BT).

"To a friend," tr. Aveling, in "World," p. 12.

"To friends," tr. Liaw Yock Fang, in CP, pp. 98-99 (BT).

"To a friend," tr. Nababan, in "Linguistic Analysis," p. 155 (B T).

"To a friend," tr. Raffel, in CPP, pp. 114-15 (B T).

"To a friend," tr. Raffel \& Salam, in Echols, IWT, p. 65.

"To a friend," tr. Raffel \& Salam, in $S P, p .33$.

"To a friend," tr. Raffel \& Salam, in José, Asian PEN, p. 162 .

"To Affandi, the painter," tr. Ali, in Flaming Earth, p. 7 . 
Kepada pelukis Affandi (continued)

Kepada peminta-minta

Kepada penjair Bohang

Kesabaran

Kita guyah lemah (originally untitled)

Krawang-Bekasi
"To the painter Affandi," tr. Boen, in Chairil Anwar, p. 75 (B T).

"To Affandi, the painter," tr. Liaw Yock Fang, in CP, pp. 78-79 (BT).

"To the painter Affandi," tr. Raffel, in CPP, pp. 9091 (B T).

"To the painter Affandi," tr. Raffel \& Salam, in Poetry Northwest, 4, 3/4 (1963/64), pp. 64-65 (B T).

"To the painter Affandi," tr. Hurustiati Subandrio, in Asian Horizon, 1, 1 (1948), pp. 48-49.

"To the painter Affandi," tr. A. Teeuw (based on Raffel's translation), in $M / L$, pp. 152, 267 (BT).

"To a beggar," tr. Dickinson, in Sharp Gravel, pp. 86-87 (B T).

"To a beggar," tr. Raffel, in CPP, pp. 52-53 (BT).

"To the poet Bohang," tr. Liaw Yock Fang, in CP, pp. 72-73 (B T).

"For the poet Bohang," tr. Raffel, in CPP, pp. 80-81 (B T).

"Epigraph from 'For the poet Bohang,"' tr. Raffel \& Salam, in $S P, \mathrm{p} .38$.

"Resignation," tr. Dickinson, in Sharp Gravel, pp. $52-53(\mathrm{BT})$.

"Patience," tr. Liaw Yock Fang, in CP, pp. 36-37 (BT).

"Patience," tr. Raffel, in CPP, pp. 32-33 (BT).

"Patience," tr. Raffel \& Salam, in SP, p. 46.

"All of us shaky and weak," tr. Dickinson, in Sharp Gravel, pp. 80-81 (BT).

"(We are shakily weak)," tr. Liaw Yock Fang, in $C P$, pp. 60-61 (BT).

"We wobble along," tr. Raffel, in CPP, pp. 62-63 (BT).

"Krawang-Bekasi," tr. Dickinson, in "Selected Social \& Ethical Values," pp. 146-47.

"Krawang-Bekasi," tr. Liaw Yock Fang, in CP, pp. 128-31 (B T).

"Krawang-Bekasi," tr. Moerdowo, Sociological Aspects, pp. 11-12.

"Krawang-Bekasi," tr. Raffel, in CPP, pp. 126-29 (B T). 
Kupu malam dan biniku

Lagu biasa

Lagu siul

Malam

Malam di pegunungan
"A whore and my wife," tr. Boen, in Chairil Anwar, p. 39 (B T).

"Night butterfly and my wife," tr. Dickinson, in Sharp Gravel, pp. 48-49 (BT).

"The whore and my wife," tr. Liaw Yock Fang, in $C P$, pp. 32-33 (BT).

"A whore and my wife," tr. Raffel, in CPP, pp. 28-29 (BT).

"An old familiar song," tr. Dickinson, in Sharp Gravel, pp. 46-47 (BT).

"An ordinary song," tr. Liaw Yock Fang, in CP, pp. 30-31 (BT).

"An ordinary song," tr. Raffel, in CPP, pp. 26-27 (BT).

"An ordinary song," tr. Raffel \& Salam, in SP, p. 37.

"An ordinary song," tr. Raffel \& Salam, in Poetry Northwest, 4, 3/4 (1963/64), pp. 64-65 (B T).

"An ordinary song," tr. Raffel \& Salam, in Raffel, "Chairil Anwar," p. 137.

"An ordinary song," tr. Raffel \& Salam, in Raffel, Development, pp. 86-87 (B T).

"A whistling tune," tr. Liaw Yock Fang, in CP, pp. 74-75 (B T).

"Whistling song," tr. Raffel, in CPP, pp. 82-83 (BT).

"Evening," tr. Beier, in Only Dust, p. 16.

"Night," tr. Liaw Yock Fang, in CP, pp. 76-77 (BT).

"Evening," tr. Raffel, in CPP, pp. 84-85 (BT).

"Evening," tr. Raffel \& Salam, in $S P$, p. 36.

"A night on the mountain," tr. Liaw Yock Fang, in $C P$, pp. 102-3 (B T).

"Evening in the mountains," tr. Raffel, in Development, pp. 106-7.

"Evening in the mountains," tr. Raffel, in CPP, pp. 122-23 (B T).

"Evening in the mountains," tr. Raffel \& Salam, in Raffel, "Chairil Anwar," p. 154. 
Mari

(originally untitled)

Merdeka

Midnight return (no Indonesian title known)

Mirat muda, Chairil muda

Mulutmu mentjubit di mulutku (originally untitled)

Night poem (no Indonesian title known)

Nisan

Nocturno (fragment)
"Let's," tr. Raffel, in Development, p. 109.

"Let's leave here," tr. Raffel, in CPP, pp. 158-59 (BT).

"Freedom," tr. Dickinson, in Sharp Gravel, pp. 78-79 (B T).

"Freedom," tr. Liaw Yock Fang, in CP, pp. 58-59.

"Free," tr. Raffel, in CPP, pp. 60-61 (BT).

"Freedom," tr. Raffel \& Salam, in SP, p. 44.

"Midnight return," tr. Walter Tauss, in Indonesia, special issue of Westerly (Oct. 1966), p. 23.

"The young Mirat and Chairil," tr. Liaw Yock Fang, in $C P$, pp. 116-17 (BT).

"Mirat's young, Chairil's young," tr. Raffel, in CPP, pp. $148-49$ (B T)

"Your mouth pinches mine," tr. Dickinson, in Sharp Cravel, pp. 84-85 (B T).

"Your mouth pinches mine," tr. Liaw Yock Fang, in $C P$, pp. 56-57 (BT).

"Your mouth," tr. Raffel, in CPP, pp. 56-57 (BT).

"Your mouth," tr. Raffel \& Salam, in SP, p. 27.

"Night poem," tr. by the poet, in Ahar, "Menjambut Selected Poems of Chairil Anwar" (review article), Basis, 13, 6 (1964), p. 174.

"Gravestone," tr. Boen, in Chairil Anwar, p. 1 (B T).

"Epitaph," tr. Dickinson, in Sharp Gravel, pp. 24-25 (BT).

"A tombstone," tr. Liaw Yock Fang, in CP, pp. 8-9 (BT).

"Gravestone," tr. Raffel, in CPP, pp. 2-3 (BT).

"A gravestone," tr. Raffel \& Salam, in Raffel, "Chairil Anwar," pp. 133-34.

"A gravestone," tr. Raffel \& Salam, in Raffel, Development, p. 81 (B T).

"Night (a fragment)," tr. Liaw Yock Fang, in CP, pp. 84-85 (BT).

"Nocturno," tr. Raffel, in his "Indonesian poetry: An introduction," Texas Quarterly, 6, 3 (1963), pp. 98-99.

"Nocturno: a fragment," tr. Raffel, in CPP, pp. 96-97 (B T). 


\section{Nocturno (fragment) (continued)}

Orang berdua

Pelarian

Pemberian tahu

Penerimaan

Penghidupan
"Nocturno (fragment)," tr. Raffel \& Salam, in Echols, $I W T$, p. 65.

"Nocturno (fragment)," tr. Raffel \& Salam, in $S P$, p. 31 .

"Nocturno," tr. Raffel \& Salam, in Raffel, "Chairil Anwar," pp. 150-51.

"Nocturno," tr. Raffel \& Salam, in Raffel, Development, p. 104 .

"Together," tr. Raffel, in CPP, pp. 86-87 (BT).

"Together," tr. Raffel \& Salam, in $S P$, p. 24.

"Together," tr. Raffel \& Salam, in Raffel, Development, p. 92 .

"The race," tr. Dickinson, in Sharp Gravel, pp. 34-35 (B T).

"The fugitive," tr. Liaw Yock Fang, in CP, pp. 20-21 (B T).

"A fugitive," tr. Raffel, in CPP, pp. 16-17 (BT).

"An announcement," tr. Liaw Yock Fang, in CP, pp. 96-97 (B T).

"A proclamation," tr. Raffel, in Development, p. 234.

"A proclamation," tr. Raffel, in CPP, pp. 116-17 (BT).

"Reception," tr. Aveling, in "World," p. 9.

"Acceptance," tr. Dickinson, in Sharp Gravel, pp. 50-51 (BT).

"Acceptance," tr. Liaw Yock Fang, in CP, pp. 394-95 (BT).

"Willingness," tr. Raffel, in CPP, pp. 30-31 (BT).

"Willingness," tr. Raffel \& Salam, in Echols, IWT, p. 64.

"Willingness," tr. Raffel \& Salam, in SP, p. 19.

"Life," tr. Dickinson, in Sharp Gravel, pp. 26-27 (B T).

"Life," tr. Dickinson, in "Selected Social \& Ethical Values," p. 16.

"Life," tr. Liaw Yock Fang, in CP, pp. 8-9 (BT).

"Life," tr. Raffel, in CPP, pp. 4-5 (BT).

"Life," tr. Raffel \& Salam, in Raffel, "Chairil Anwar," pp. 134-35 (BT).

"Life," tr. Raffel \& Salam, in Raffel, Development, pp. 82-83. 
Perdjurit djaga malam

Perhitungan

Persetudjuan dengan Bung Karno

Puntjak

Rumahku

Sadjak buat Basuki Resobowo
"Night watch," tr. Ali, in Flaming Earth, p. 12.

"Night watch," tr. Liaw Yock Fang, in CP, pp. 110-11 (BT).

"A sentry at night," tr. Raffel, in CPP, pp. 136-37 (B T).

"Calculation," tr. Dickinson, in Sharp Gravel, pp. 60-61 (BT).

"Calculation," tr. Liaw Yock Fang, in CP, pp. 38-39 (B T).

"A reckoning-up," tr. Raffel, in CPP, pp. 34-35 (BT).

"Pact with Brother Karno," tr. Dickinson, in "Selected Social \& Ethical Values," pp. 147-48.

"An agreement with Bung Karno," tr. Liaw Yock Fang, in $C P, \mathrm{pp} \cdot 106-7(\mathrm{BT})$.

"Agreement with Friend Soekarno," tr. Raffel, in CPP, pp. 130- 31 (B T).

"Agreement with Friend Soekarno," tr. Raffel \& Salam, in $S P, \mathrm{p} .47$.

"An agreement with Friend Sukarno," tr. Raffel \& Salam, in Raffel, "Chairil Anwar," p. 140.

"An agreement with Friend Sukarno," tr. Raffel \& Salam, in Raffel, Development, p. 89 (BT).

"Puntjak," tr. Boen, in Chairil Anwar, p. 88 (BT).

"Top of mountain," tr. Liaw Yock Fang, in CP, pp. $110-11$.

"On top of the mountain," tr. Raffel, in CPP, pp. 138-39 (B T).

"At a mountain resort," tr. Raffel \& Salam, in SP, p. 35.

"My home," tr. Dickinson, in Sharp Gravel, pp. 62-63 (BT).

"My home," tr. Dickinson, in "Selected Social \& Ethical Values," p. 136.

"My house," tr. Raffel, in CPP, pp. 38-39 (BT).

"My house," tr. Raffel \& Salam, in SP, p. 23.

"A poem for Basuki Resobowo," tr. Liaw Yock Fang, in $C P, \mathrm{pp} .100-101$ (B T).

"A poem for Basuki Resobowo," tr. Nababan, in "Linguistic Analysis," p. 188 (B T).

"Poem for Basuki Resobowo," tr. Raffel, in CPP, pp. 118-19 (B T). 
Sadjak buat Basuki

Resobowo

(continued)

Sadjak putih

Sebuah kamar

Selama bulan menjinari dadanya djadi pualam (originally untitled)

Selamat tinggal

\section{Semangat}

See Aku (semangat)

1943
"Poem for Basuki Resobowo," tr. Raffel \& Salam, in $S P, \mathrm{p} .28$.

"Poem for Basuki Resobowo," tr. Raffel \& Salam, in Raffel, "Chairil Anwar," pp. 153-54.

"Poem for Basuki Resobowo," tr. Raffel \& Salam, in Raffel, Development, p. 106.

"A love song," tr. Liaw Yock Fang, in CP, pp. 68-69 (BT).

"A pure rhyme," tr. Raffel, in CPP, pp. 72-73 (B T).

"A pure rhyme," tr. Raffel \& Salam, in SP, p. 43.

"A room," tr. Liaw Yock Fang, in CP, pp. 76-77 (B T).

"A room," tr. Raffel, in CPP, pp. 88-89 (BT).

"A room," tr. Raffel \& Salam, in "Chapbook of contemporary Asian Poetry," The Beloit Poetry Journal, 13, 2 (1962-63), pp. 22-23.

"A room," tr. Raffel \& Salam, in $S P$, p. 21.

"As long as the moon shines on his breast and becomes marble," tr. Liaw Yock Fang, in CP, pp. 114-15 (BT).

"While the moon gleams," tr. Raffel, in CPP, pp. 14243 (BT).

"As long as the moon," tr. Raffel \& Salam, in SP, p. 39.

"Goodbye," tr. Dickinson, in Sharp Gravel, pp. 74-75 (BT).

"Good-bye," tr. Liaw Yock Fang, in CP, pp. 54-55 (BT).

"Goodbye," tr. Raffel, in CPP, pp. 54-55 (BT).

"Goodbye," tr. Raffel \& Salam, in $S P$, p. 25.

"1943," tr. Achdiat Karta Mihardja, in "Some Indonesian verse forms," Hemisphere, 8, 3 (1964), p. 25.

"1943," tr. Boen, in Chairil Anwar, p. 63 (BT).

"1943," tr. Liaw Yock Fang, in CP, pp. 62-63 (BT).

"1943," tr. Nababan, in "Linguistic Analysis," pp. 177-78 (BT).

"1943," tr. Raffel, in CPP, pp. 66-67 (BT).

"1943," tr. Raffel \& Salam, in Raffel, "Chairil Anwar," p. 146 . 
1943

(continued)

Sendiri

Sendja di pelabuhan ketjil

Siap-sedia

Sia-sia
"1943," tr. Raffel \& Salam, in Raffel, Development, p. 97 (B T).

"Alone," tr. Dickinson, in Sharp Gravel, pp. 36-37 (BT).

"Alone," tr. Liaw Yock Fang, in CP, pp. 18-19 (BT).

"Alone," tr. Raffel, in CPP, pp. 14-15 (B T).

"Dusk in the harbour," tr. Ali, in Flaming Earth, p. 6.

"Dusk in the harbour," tr. Ahmed Ali, in Asian Horizon [London], 3, $1(1950 / 51)$, p. 65 .

"Dusk in the harbour," tr. Ahmed Ali, in Wigmore, Span, p. 165.

"Twilight at a little harbour," tr. Boen, in Chairil Anwar, p. 81 (B T).

"Dusk in a small harbour," tr. Liaw Yock Fang, in CP, pp. 90-91 (B T).

"Twilight at a little harbor," tr. Raffel, in CPP, pp. 104-5 (BT).

"Twilight at a little harbor," tr. Raffel \& Salam, in SP, p. 17 .

"Dusk in a little harbor," tr. Raffel \& Salam, in José, Asian PEN, p. 241.

"Twilight at a little harbor," tr. Raffel \& Salam, in Raffel, "Chairil Anwar," pp. 149-50.

"Twilight at a little harbor," tr. Raffel \& Salam, in Raffel, Development, p. 103.

"Twilight at a little harbor," $\operatorname{tr}$. A. Teeuw (based on Raffel's translation), in $M I L, p p .156-57,268$ (BT).

"To arms," tr. Liaw Yock Fang, in CP, pp. 70-71 (BT).

"We're ready," tr. Raffel, in CPP, pp. 76-79 (BT).

"Useless," tr. Aveling, in "World," p. 10.

"Futility," tr. Dickinson, in Sharp Gravel, pp. 32-33.

"Futility," tr. Liaw Yock Fang, in CP, pp. 14-15.

"In vain," tr. Raffel, in CPP, pp. 10-11 (BT).

"In vain," tr. Raffel \& Salam, in Echols, IWT, p. 66.

"In vain," tr. Raffel \& Salam, in SP, p. 27.

"In vain," tr. Raffel \& Salam, in Raffel, "Chairil Anwar," pp. 135-36.

"In vain," tr. Raffel \& Salam, in Raffel, Development, p. 84 . 
Situasi

Sorga

Suara malam

Sudah dulu lagi terdjadi begini (originally untitled)

Tak sepadan
"Situation," tr. Liaw Yock Fang, in CP, pp. 94-95.

"Situation," tr. Raffel, in CPP, pp. 110-11 (BT).

"Paradise," tr. Ali, in Flaming Earth, p. 8.

"Paradise," tr. Ahmed Ali and Idham, in Perspective of Indonesia, supplement to The Atlantic Monthly, 197 (June 1956), p. 123.

"Paradise," tr. Liaw Yock Fang, in CP, pp. 102-3 (B T).

"Paradise," tr. Muhammad Haji Salleh, in Tradition and Change, p. 21.

"Heaven," tr. Raffel, in CPP, pp. 120-21 (BT).

"Heaven," tr. Raffel \& Salam, in Raffel, AMIP, p. 68.

"Heaven," tr. Raffel \& Salam, in SP, p. 42.

"Heaven," tr. Raffel \& Salam, in Raffel, "Chairil Anwar," p. 153.

"Heaven," tr. Raffel \& Salam, in Raffel, Development, pp. 105-6.

"Voice of the night," tr. Dickinson, in Sharp Gravel, pp. 38-39.

"Voices from the night," tr. Liaw Yock Fang, in $C P$, pp. 22-23 (BT).

"The voice of the night," tr. Raffel, in CPP, pp. 18-19 (B T).

"Like this," tr. Raffel, in CP, pp. 132-33 (BT).

"Since long ago it has been thus," tr. Liaw Yock Fang, in $C P$, pp. 108-9 (B T).

"Not meant for each other," tr. Dickinson, in Sharp Gravel, pp. 30-31.

"Inequality," tr. Liaw Yock Fang, in CP, pp. 12-13 (BT).

"Unequalled," tr. Sularko, in Poetry, the Australian International Quarterly of Verse [Melbourne], 25 (December 1947), pp. 35-36.

"Garden retreat," tr. Dickinson, in Sharp Gravel, pp. 44-45.

"A garden," tr. Liaw Yock Fang, in CP, pp. 28-29 (BT).

"Garden," tr. Muhammad Haji Salleh, in Tradition and Change, pp. 15-16.

"Our garden," tr. Raffel, in CPP, pp. 24-25 (B T). 
Taman

(continued)

Tjatetan th. 1946
"Our garden," tr. Raffel \& Salam, in $S P$, p. 38.

"Our garden," tr. Raffel \& Salam, in Raffel, "Chairil Anwar," pp. 144-45.

"Garden," tr. Raffel \& Salam, in Raffel, Development, p. 96.

"Note on 1946," tr. Liaw Yock Fang, in CP, pp. 80-81 (B T).

"Record of 1946," tr. Peter Lucich, in Indonesia, special issue of Westerly (Oct. 1966), p. 21.

"Notes for 1946," tr. Raffel, in CPP, pp. 92-93 (BT).

"Notes for 1946," tr. Raffel \& Salam, in Echols, IWT, pp. 63-64.

"Notes for 1946," tr. Raffel \& Salam, in $S P$, p. 48.

Tjemara menderai sampai djauh

See Derai-derai tjemara

Tjerita

Tjerita buat Dien Tamaela
"A story," tr. Boen, in Chairil Anwar, pp. 132-33.

"A story," tr. Dickinson, in Sharp Gravel, pp. 70-71.

"A story," tr. Liaw Yock Fang, in CP, pp. 50-51 (BT).

"A story," tr. Raffel, in CPP, pp. 48-49 (BT).

"Story for a girl," tr. Ali, in Flaming Earth, pp. 9-10.

"Story for a girl, Dien Tamaela," tr. Ahmed Ali, in Wigmore, Span, pp. 338-39.

"Story for a girl, Dien Tamaela," tr. Ahmed Ali and Idham, in Perspective of Indonesia, supplement to Atlantic Monthly (June 1956), p. 113.

"A story for Dien Tamaela," tr. Liaw Yock Fang, in $C P, \mathrm{pp} .86-87$ (B T).

"Story for Dien Tamaela," tr. Nababan, in "Linguistic Analysis," pp. 161-62.

"A tale for Dien Tamaela," tr. Raffel, in CPP, pp. 98101 (BT).

"A tale for Dien Tamaela," tr. Raffel \& Salam, in SP, pp. 40-41.

"A tale for Dien Tamaela," tr. Raffel \& Salam, in Raffel, $A M I P$, pp. 69-70.

"A tale for Dien Tamaela," tr. Raffel \& Salam, in José, Asian PEN, p. 158.

"A tale for Dien Tamaela," tr. Raffel \& Salam, in Raffel, "Chairil Anwar," pp. 151-52.

"A tale for Dien Tamaela," tr. Raffel \& Salam, in Raffel, Development, p. 105. 
Tjerita buat Dien

Tamaela (continued)

Tjintaku djauh di pulau

Tuti artic

Wadjah

Waktu djalan/aku tak tahu nasib waktu
"Story for Dien Tamaela," tr. Justus M. van der Kroef, in "Modern Trends in Indonesian Literature," Journal of East Asiatic Studies, 3 (1954), pp. 142-43.

"My love far in the islands," tr. Derwent May, in Shimer, Mentor Book, pp. 68-69.

"My beloved is afar off, on an island," tr. A. H. Johns, BKI, 120, 4 (1964), pp. 402, 408.

"My love is far away on an island," tr. Liaw Yock Fang, in CP, pp. 92-93 (BT).

"My beloved is far away on an island," tr. Nababan, in "Linguistic Analysis," pp. 191-92.

"My love's on a faraway island," tr. Raffel, in CPP, pp. 106-7.

"My love's on a far-away island," tr. Raffel \& Salam, in "Chapbook of Contemporary Asian Poetry," The Beloit Poetry Journal, 13, 2 (1962-63), pp. 21-22.

"My love's on a faraway island," tr. Raffel \& Salam, in $S P, p .20$.

"My love's on a faraway island," tr. Raffel and Salam, in Shimer, Mentor Book, p. 68.

"Tuti Arctic," tr. Liaw Yock Fang, in CP, pp. 104-5 (B T).

"Tuti Arctic," tr. Muhammad Haji Salleh, in Tradition and Change, p. 50.

"Tuti's ice cream," tr. Raffel, in CPP, pp. 124-25 (B T).

"Tuti's ice cream," tr. Raffel \& Salam, in Echols, IWT, p. 64 .

"Tuti's ice cream," tr. Raffel \& Salam, in $S P$, p. 22.

"Tuti's ice cream," tr. Raffel \& Salam, in Raffel, "Chairil Anwar," pp. 154-55.

"Tuti's ice cream," tr. Raffel \& Salam, in Raffel, Development, p. 107.

"The face," tr. Ali, in Flaming Earth, p. 25.

"The time goes on. I do not know what will be," tr. Anas Ma'ruf, in Anas Ma'ruf, "Modern Indonesian literature," a speech delivered 15th September 1957 before the students of Seoul National University (Seoul, 1957), p. 3 (BT). 
"?," tr. Dickinson, in Sharp Gravel, pp. 82-83.

"?," tr. Liaw Yock Fang, in CP, pp. 60-61.

"?," tr. Raffel, in CPP, pp. 64-65 (BT).

"?," tr. Raffel \& Salam, in $S P$, p. 31.

"?," tr. Raffel \& Salam, in Raffel, "Chairil Anwar," pp. 147-48.

"?," tr. Raffel \& Salam, in Raffel, Development, p. 100. 